\title{
On the Similarities and Differences of Yan Ou's Ci
}

\author{
Xiaotong $\mathrm{Li}^{1}$ \\ ${ }^{1}$ Chinese International Education, Northeast Agricultural University, Harbin, China \\ Correspondence: Xiaotong Li, Chinese International Education, Northeast Agricultural University, 600 \\ Changjiang Road, Xiangfang District, Harbin, Heilongjiang, China. E-mail: 251728675@qq.com
}

Received: October 10, 2021

Accepted: November 10, 2021

Online Published: November 18, 2021

doi:10.20849/ajsss.v6i4.951

URL: https://doi.org/10.20849/ajsss.v6i4.951

\begin{abstract}
Since the Northern Song Dynasty, Ouyang Xiu's Ci, as the highest achievement in the creation of Ci Poetry in the early Song Dynasty, has always been praised, cited and learned. Their poems have the same atmosphere of graceful poetry, with small images, gentle and delicate language and same feelings. They have many similarities, but they also show their own personality characteristics. They are different in material selection, expression methods and emotions. My work will analyze the similarities and differences between the two from the perspective of knowing people and discussing the world.
\end{abstract}

Keywords: Yan Shu, Ouyang Xiu, poems

Yan Shu (991-1055) was named Yongshu. He was born in Fuzhou, Jiangxi Province. He was a graceful poet. His identify was a Jinshi in jingdezhong and was a middle official to prime minister in Qingli. Ouyang Xiu (1007-1072) was named Yongshu. He was a native of Yongfeng, Jiangxi Province. He named himself as the Drunkard lay and 61lay. In 1061 of the 6th year of Jiayou, he was an official and learned political affairs. Similarly, the two are fellow townsmen, with a difference in the years of birth and death of ten years. They are both officials and prime ministers, and they are both influenced by Feng Yansi's graceful style of $\mathrm{Ci}$ in the Southern Tang Dynasty, so they are called by later generations. Feng Xu, a scholar in the Qing Dynasty, said that Yan Shu and Ouyang Xiu were jointly influenced by Feng Yansi and opened the "Jiangxi School". The difference is that their childhood experiences are quite different, their official career and political opinions are contradictory, and their personalities are also very different, which leads to the gradual deterioration of their relationship and finally to the point of making enemies.

\section{Career Experience}

Chen Yange said that Chinese culture, after thousands of years of evolution, reached its peak at the time of Zhao and Song dynasties. The main reason is that Zhao Kuangyin had "released his military power with a cup of wine 杯酒释兵权" just after he ascended the throne, thus laying the national policy of scholar bureaucrats and the emperor ruling the world together. It can be said that the Song Dynasty is a dynasty that strictly ruled by literature in the general history of five thousand years. Emphasizing literature over martial arts can be said to be a typical feature of the Song Dynasty. This also provides a valuable opportunity for the literati, and the status of literati has been improved. In the early Northern Song Dynasty, the examination contents of the imperial examination system in the Tang Dynasty were still used, and scholars were still selected for ci and Fu. Yan Shu will be the most shining star in such an era. The history of the Song Dynasty records that he was able to write at the age of seven. In the early years of Jingde, Zhang Zhibai arrived Jiangnan and recommended him as a child prodigy. When Zhenzong saw that he was only 14 years old, but he was "神气不慑" and "援笔立成", he rewarded him with the title of Jinshi. The next day, when he reexamined the theory of ci and Fu, he said frankly that he had practiced this topic and asked for a change of topic, which made the emperor feel that he was honest and did not deceive. When he finished the Fu, the emperor praised it many times and expressed his appreciation. Since then, Yan Shu's career has been smooth. He has been successively appointed as Zhishu, Shangshu, member of the household department, wailang and other official positions, and the emperor attaches great importance to him. It said that “帝每访以事, 晏殊率用方寸小纸细书, 答奏后, 并稿封之。皇上重其慎密。” During the reign of Qianxing, he was impeached by the censor because he disobeyed the will of Empress Dowager Liu and angrily broke the front teeth of his attendants with Chaohu in Yuqing palace. In the fifth year of Tiansheng (1027), he was demoted to Xuanzhou and later transferred to yingtianfu. Here, he pioneered a large-scale education and invited Fan Zhongyan to give lectures, which was the first move after the abolition of the school 
in the Five Dynasties. Later, the Academy, together with Bailudong academy, shigu academy and Yuelu Academy, was called the four academies in the early Song Dynasty. In the third year of Qingli (1043), when he was Prime Minister, together with Fan Zhongyan, he advocated state and county schools and reform the teaching content, and set up professors in official schools. Since then, there have been official schools from the capital to counties. This is the famous "Qingli Xingxue". Ouyang Xiu also praised it as "自五代以来, 天下学废, 兴自公始" [Ouyang Xiu \{Yan Yuan offered the monument of Gongshu's old learning\}]. From this point of view, although Yan Shu was relegated in his life, he set up education, won the praise of future generations to a certain extent, and was successful in his official career.

But compared with this, Ouyang Xiu has the same talent, but he doesn't have the same treatment as a child prodigy. The year Ouyang Xiu was just born, Yan Shu was already famous in the capital. He lost his father when he was young. Only his mother taught him to read and write with a silver pole did he not lose the opportunity to read. He is talented and loves reading. When he got Mr. Changli's collection at the age of ten, he can't put it down. However, his road to the imperial examination was very bumpy. In the first year and the fourth year of Tiansheng, he unexpectedly failed in the imperial examination. Fortunately, in the seventh year, he scored three yuan in a row. In the eighth year of the imperial examination, he was only sung as 14 by the Emperor Renzong. Coincidentally, the examiner this time was no other person, it was Yan Shu, who failed to win the first prize. He was not inferior in skill, but his edge was too exposed to file his spirit. Although he did not win the first position in the exam, he also obtained certain official positions. In the ninth year of Tiansheng (1031), Ouyang Xiu arrived in Luoyang and met a very important figure, Qian Weiyan. From a certain point of view, Qian Weiyan gave Ouyang Xiu enough time to ponder over the creation of ancient prose, which enabled us to have good articles to appreciate in future generations which can be said that Qian Weiyan has contributed for thousands of years.This period time in Luoyang was the best time of Ouyang Xiu's life, which also laid a certain foundation for his literary skills. Later, he was demoted. He lamented that "曾是洛阳花下客, 野芳虽晚不须嗟” [戏答元 珍], which also showed his broad-minded mind of letting things go in the same way as he did in the story of the drunken Weng Pavilion(《醉翁亭记》) . In the first year of Jingyou (1034), he returned to Beijing to do the collation of the pavilion. He still took "座上客常满, 樽中酒不空" as his motto. Three years ago, he and his good friend Fan Zhongyan participated in the reform of changing the accumulated poverty and weakness of the Northern Song Dynasty, and was eventually demoted to Yiling because they infringed on interest groups. Later, although he returned to Beijing again, it didn't last long. In the fifth year of Qingli (1045), the "Qingli New Deal" failed, and Ouyang Xiu was demoted to Chuzhou. There, Ouyang Xiu was a good prefect who shared happiness with the people, and another excellent work spread through the ages. Later, he also worked as a Hanlin bachelor and compiled the book of Tang. In the second year of Jiayou (1036), he was the examiner of the Ministry of rites. He advocated a plain style of writing, and successively enrolled Su Shi, Su Zhe, Zeng Gong and other great poets of future generations.

Whether he was demoted to Yiling or Chuzhou, it is a witness to Ouyang Xiu's rough life experience. In the second year of emperor Renzong Kangding's reign (1042), Yan Shu became a privy envoy in charge of military work. At that time, Fan Zhongyan and others were resisting Xixia on the border. Yan Shu held a banquet, and Ouyang Xiu also participated in it. He wrote a poem on the spot, "主人与国同休戚, 不惟喜悦将丰登。须怜铁 甲冷彻骨, 四十馀万屯边兵。”《晏太尉西园贺雪歌》Yan Shu felt that he was embarrassing himself in public. From then on, he hated Ouyang Xiu, and later said to others that "一知举时门生, 已过矣". This incident became the fuse for Yan Ou's bad relationship to a formal break. Yan Shu was proud of his official career and rarely experienced ups and downs, while Ouyang Xiu was born in a poor family and failed to meet his talents. His political ideals tended to reform and innovation. They are both parties to the Qingli new deal. Yan Shu is not keen on the new deal, but Ouyang Xiu actively participates in it. In his opinion, Yan Shu is a manifestation of being wise and afraid of taking responsibility. Political ideas also led the two to go farther and farther. On the other hand, Ouyang Xiu is bold and open-minded. He likes drinking. It is a great pleasure for Ouyang Xiu to get together with two or three close friends, have fun and talk loudly. Yan Shu disagrees with Ouyang Xiu's way of gathering. He thinks that he has too much pomp and gathers people to make noise, which is not the style of literati and refined scholars. There are also many differences in their ways of life, It makes the old relationship between teachers and students weaker and weaker, like strangers.

\section{Similarities of CI Achievements}

Yan Shu, as a poet of the Northern Song Dynasty who was born not long from the Southern Tang Dynasty, naturally inherited the graceful style of the Southern Tang Dynasty. He and Li Qingzhao, Liu Yong and Li Yu were the four flags of the graceful style, one of which was called "qingchang". In addition to expressing the representative work of parting and acacia, 《蝶恋花》, there are also the melancholy and lonely works of “无可 
奈何花落去，似曾相识燕归来，小园香径独徘徊”, as well as the scenes of "疑怪昨宵春梦好，元是今朝斗 草赢, 笑从双脸生" which are full of a happy atmosphere of girls pick mulberry and plant grass. These poems are included in 《珠玉词》, which is a well-known masterpiece. There is no lack of finishing touches such as " 日常飞絮轻" and "翠叶藏莺, 朱帘隔燕". The style of Ci poetry is inherited from the Five Dynasties as a whole, and the language is clear and graceful. Most of the ci poetry is mostly in Xiaoling. They are good at sketching a scene with less pen and ink. Most of them lament the passage of time, the aging of life and the feeling of sadness and parting. Among them, the whole Ci Poetry of 《破阵子》(燕子来时) is full of joy and joy, which is unique in Yan's poetry and belongs to a work with special feelings. Based on his different identity and status, Yan Shu inherited the creation paradigm of five pronouns in the late Tang Dynasty rather than the middle Tang Dynasty. Between Feng Yansi and Li's father and son, Yan Shu is more inclined to learn from Feng Yansi, which not only lies in the similar social status of Yan and Feng, but also lies in the similarity of the meaning of officials hidden behind status.

Ouyang Xiu's poetic style is most similar to Feng Yansi's graceful poetic style, which is one of the reasons why Yan Ou can be called together. They have well absorbed the characteristics of the graceful CI style, but to a certain extent, coupled with their own opinions, the CI style has no affectation and mysterious Jiangnan atmosphere in the Southern Tang Dynasty. In the long river of poetry creation, it plays an important role of "connecting the preceding and the following". Compared with Yan Shu's inheritance, Ouyang Xiu's words are obviously more enlightening. For example, in a farewell speech in Ou Gong's later works, "行乐直须年少, 樽前 看取衰翁". Although it is to see off your friends, it has no sentimental meaning. It is the ideological connotation of saying that life is impermanent and you need to enjoy it in time. "手中堂前垂柳, 别年几度春凤" also has the meaning of high spirited upward. This is one of Ou Gong's poems that best reflects his thoughts and feelings in his heart. It is also a song different from Yan Shu's Ci style. Similarly, Ou once wrote the same spring sorrow poem as Yan's poem "《踏莎行》 (小径红), 《蝶恋花》(谁道闲情). 愁因春起, 见花生愁, 借酒消愁, 红颜 憔悴愁更愁, 独立小桥还是愁. How can he get a word of sorrow in the whole article, and the author's poetic skills are self-evident. Another example is "平芜尽处是春山, 行人更在春山外"(《踏莎行》). The artistic conception is no longer confined to small places, and the breadth of mind is also different from Yan Shu, which is the epitome of the author's mind.

Wang Guowei commented on Yan Ou's Ci style in his book "人间词话". For example, he commented on the word "绿杨楼外出秋千" in 《浣溪沙》 in 21st. Although he used Feng Yansi's "柳外秋千出画墙", his writing was more exquisite and meticulous. The 22nd commented that "I said Feng Zhengzhong's spring in the jade building... Uncle Yong seems to have studied this kind all his life" [Wang Guowei. Human CI $\{\mathrm{m}\}$ Sichuan literature and Art Publishing House, June 2019]. Although Feng Yansi's Ci still has the style of the Five Dynasties, his ci pattern is grand and the artistic conception is far-reaching, creating the style of $\mathrm{Ci}$ in the Northern Song Dynasty, while Ou Jiu has studied it in this style to form his own style. 27th commented that "Uncle Yong" 人间自是有情痴, 此恨不关风与月"," 直须看尽洛城花, 始与东风容易别 ", and he is calm in his boldness, so he is especially high". From these comments on Wang Guowei's Ou poetry, we can see the high level of Ou poetry.

Liu Xizai also mentioned in 《艺概》 that "冯延已之词, 晏同叔得其俊, 欧阳永叔得其深" [Liu Xizai. Yigai $\{\mathrm{m}\}$ China Bookstore, January 2019] that is to say, the vivid use of Yan Shu's words follows Feng Yansi's poetic style and artistic conception, while Ouyang Xiu has more internal literary skills, which can be seen from the use of Ouyang Xiu's word "出" in the above. In terms of subject matter, the three people mostly give leisurely speeches, or feel sad about the scenery, or sad about spring and autumn, or write about the resentment in the boudoir. The difference is that Feng Yansi was born at an untimely time. When he was an adult, the Southern Tang Dynasty was already full of wind and rain. Therefore, there is a sense of "involuntarily" unrest in his poems, which is absolutely nothing in Yan's poems and Ou poems.

\section{Differences of CI Achievements}

Although Yan Ou's Ci has similarities in style and language,there are subtle differences between them in the description of artistic conception and the expression of emotion. This also stems from their different preferences and moods.

First of all, in the part of image selection and artistic conception description, Yan Shu is more willing to select images such as swallow and sunset, such as “夕阳西下几时回”“似曾燕归来”(《浣溪沙》) “燕子双飞去”(《蝶 恋花》) “燕子来时新社” (《破阵子》) “斜阳却照深深院” (《踏莎行》) “斜阳却照阑干”“双燕欲归时 节” (《清平乐》. Swallows are birds that come and go from autumn to spring, but people are old and fleeting. When the sunset sets, they will rise the next day, but people are not. There is a kind of "年年岁岁花相似, 岁岁 
年年人不同" It reflects the poet's continuous thinking about the vast world and is a form of expressing philosophy. Ou poetry is very different. It mostly uses the image of willow, which is homophonic to "留", which gives the willow tree a sentimental emotional color, and more reflects the sentimental and deep characteristics of Ou poetry, such as "“溪桥柳细” (《踏莎行》) “月上柳梢头” (《生查子》) “杨柳堆烟”（《蝶恋花》）“垂 柳阑干尽日风”(《采桑子》).

Secondly, the life scenes described are also somewhat different. Yan's poetry focuses on the scenes in the Pearl curtain painting hall. For example, he writes about his wife's resentment or parting melancholy from the perspective of the third person, and has less investment in emotion. His writing style is to watch and move.Ou poetry, however, has more life scenes and writes in the first person, which seems flesh and blood, more emotional investment and sincere.

The last part is the emotional expression part. Yan CI has less emotional expression, but it has the characteristics of handsome. It is reflected in thinking in emotion. Even if he describes boudoir resentment, he can jump out of it. For a more rational analysis, he is a seamless poet who can combine poetry with rational thinking. He is used to giving emotion to the description of scenery rather than expressing his feelings in a straightforward way, Leave readers unlimited thinking space. On the contrary, Ou CI poured a lot of emotion into poetry, moving with delicate but bold emotion, and winning with emotion, which is reflected in depth and truth. If Yan Shu is compared to a rational poet, Ouyang Xiu is a perceptual poet.

By comparison, it is still due to their different mood preferences. As a dignitary, although Yan Shu often lingered in banquets, the noise of the outside world never interfered with his inner peace. He always participated in this kind of meeting as a bystander. Therefore, he is an introverted and less emotional poet.

Ouyang Xiu is very different. Although he is diligent in dealing with political affairs and benefiting the people, he does not delay his love for guests and visiting between mountains and rivers. He is a bold and broad-minded poet, which can be seen from his preference for wine.

Wine is the symbol of Ouyang Xiu's free,extroverted and casual character. From middle-aged "drunkard" to old age "61 scholar" Ouyang Xiu's naming of the two most important titles in his life has a lot to do with wine. This role further shows the deep significance of wine in his life. In Ouyang Xiu's eyes, wine is the carrier of mood. People are full of friends, talk loudly, and should be accompanied by wine. He has been relegated and frustrated in life, so he should have good wine in his hand. Wine enters the sad heart and has turned into a breath Chang's poetry makes Ouyang Xiu's intention in his poetry more broad and grand.

\section{The Influence and Status of Yan Ou CI on Later Generations}

Apart from Yan Shu's familiar poetry works, such as 《浣溪沙》 (一曲新词) 以及《破阵子》(燕子来时), other works are not famous enough in later generations. Yan Shu integrates rational thinking into lyricism. Even if he always melancholy and moody, he can also show a kind of rational thinking, revealing a kind of harmonious and broad-minded rational reflection in his words of tenderness like water. [Duan Xinxin. Research on the reasons for the differences in the status of Yan Shu's Poems [J]. Chinese Journal, 2016 (08): 57-58] it is precisely because it is mellow and exquisite, which is very consistent with Confucianism. What is very different from this is that Ouyang Xiu shows a greater love for mountains and rivers. Intoxicated with mountains and rivers is the ideal state of his life. Growing up and living with nature seems more free and easy, which deeply confirms the Taoist thought of the unity of heaven and man. Although both Confucianism and Taoism have the commonness of loving mountains and rivers and advocating nature, Taoism loves mountains and rivers for the sake of enriching sensory aesthetics, while Confucianism Values moral values and ethics. The same love for mountains and rivers is different in nature. Taoism is more sincere and natural than Confucianism.

Compared with Yan Shu, Ouyang Xiu was a leader in the literary world of the Northern Song Dynasty. He is not only proficient in the creation of poetry and prose, but also has made quite brilliant achievements in ancient prose. He inherited Han Yu's ancient style. Yan Shu can be said to be limited to the creation of poetry and did not have much attainments in other literary styles.

In addition, Ouyang Xiu has made achievements in classics, history and archaeology, and his unique personality charm has laid a solid foundation for his prominent position in the literary world and later generations.

\section{Conclusion}

Although Yan Ou's Ci works did not exceed the barriers of the late Tang and Five Dynasties, they all had their own style characteristics in the creation and combination of images and the rendering of artistic conception and atmosphere, forming their own creative personality and affecting the subsequent poets. [Duan Yongli. Subtle and gentle have their own merits -- on the similarities and differences of Yan Ou's Ci style [J]. Journal of 
Heilongjiang Institute of education, 2002 (03): 73-74 + 78.] their joint statement is historical inevitability, because they have too many similarities in CI style and accidental factors. Their personal experiences are very different, resulting in great differences in personality and temperament, but it is undeniable that, Both of them have left quite magnificent cultural treasures for future generations.

\section{References}

Duan, X-X. (2016). A probe into the reasons for the differences in the status of Yan Shu's Poems. Chinese Journal, (8), 57-58.

Duan, Y-L. (2002). Subtle, soft and euphemistic have their own merits -- on the similarities and differences of Yan Ou's Ci style. Journal of Heilongjiang Institute of Education, (3), 73-74, 78.

Liu, X-Z. (2019, January). Art Overview. China Bookstore.

Shao, M-Z. (2020, March). Yan Shu and the evolution of literary style in the early Northern Song Dynasty. Qilu Journal.

Wang, G-W. (2019, June). Human CI Hua. Sichuan Literature and Art Publishing House.

\section{Copyrights}

Copyright for this article is retained by the author(s), with first publication rights granted to the journal.

This is an open-access article distributed under the terms and conditions of the Creative Commons Attribution license (http://creativecommons.org/licenses/by/4.0/). 